Jurnal Jeumpa, 8 (1) Januari -Juni 2021

\title{
IDENTIFIKASI TIPE KERUSAKAN POHON DI WISATA HUTAN LINDUNG KOTA LANGSA
}

\section{IDENTIFICATION OF TYPES OF DAMAGE TO TREES FOUND IN THE PROTECTED FOREST TOUR OF LANGSA CITY}

\author{
Nurul makhfirah', Dea Utami², Fairuz Sena ${ }^{3}$, Vivi Mardina ${ }^{4}$, Yeni Rimadeni ${ }^{5}$ \\ Program Studi Biologi, Fakultas Teknik, Universitas Samudra \\ Poltekkes Kemenkes Aceh, Aceh Besar, Indonesia \\ email: vmardina@unsam.ac.id
}

\begin{abstract}
Abstrak
Indonesia merupakan salah satu Negara megabiodiversitas yang memiliki variasi jenis hutan. Peran hutan sebagai paru-paru kota untuk masyarakat diwujudkan pemerintah melalui hutan kota. Salah satunya adalah Taman Wisata Hutan Lindung kota Langsa, Aceh yang memiliki sekitar 62 jenis pohon atau berjumlah 1273 pohon dengan luas $\pm 10 \mathrm{Ha}$. Peranan hutan kota dipengaruhi oleh kesehatan hutan dalam bentuk kondisi kerusakan pohon. Penelitian ini merupakan langkah awal untuk mengetahui jenis penyakit pohon yang terdapat di Taman Wisata Hutan Lindung Kota Langsa sebagai langkah awal pemeliharaan hutan kota. Metode yang digunakan adalah metode jelajah (Cruise method) dengan observasi langsung terhadap objek yang diteliti. Hasil yang diperoleh ialah terdapat enam tipe kerusakan pohon yaitu (1) kanker yang terdapat pada pohon kayu alim (Lepidium sativum L.), (2) Luka terbuka yang terdapat pada pohon tempinis (Sloetia elongata), (3) gerowong yang terdapat pada pohon sumatra (Taxus baccata L.), (4) Brum yang terdapat pada pohon jati (Tectona grandis L.f.), (5) keropos akibat serangan rayap yang terdapat pada pohon puring (Croton laevigatus Vahl), dan (6) serangan jamur pada pohon pasak bumi (Eurycoma longifolia).
\end{abstract}

Kata kunci: Kerusakan, Kota Langsa, Hutan Lindung

\begin{abstract}
Indonesia is one of the mega-biodiversity countries that have a variety of forest types. The role of the forest as the lungs of the city for the community is realized by the government through urban forests. One of them is the Langsa City Protected Forest Tourism Park, Aceh which has about 62 species of trees or a total of 1273 trees with an area of $\pm 10 \mathrm{Ha}$. The role of urban forests is influenced by forest health in the form of tree damage conditions. This study is the first step to determine the types of tree diseases found in the Langsa City Protected Forest Tourism Park as the first step in maintaining the urban forest. The method used is the cruise method with direct observation of the object under study. The results obtained were that there were six types of tree damage, namely (1) cancer found in alim trees (Lepidium sativum L.), (2) open wounds found in tempinis trees (Sloetia elongata), (3) tunnels found in trees. Sumatra (Taxus baccata L.), (4) Brum found on teak trees (Tectona grandis Lf), (5) porous due to termite attack found on puring trees (Croton laevigatus Vahl), and (6) fungal attacks on peg trees earth (Eurycoma longifolia).
\end{abstract}

Keywords: Damage, Langsa City, Protected Forest 


\section{Pendahuluan}

Indonesia merupakan salah satu negara yang kaya keindahan alam dengan beragam jenis hutan yang bervariasi, sehingga dijuluki sebagai "negara mega biodiversty" (Tuheteru dan Mahfudz, 2012). Di dunia, Indonesia menempati posisi ke-9 negara mega biodiversitas setelah Afrika Selatan, Amerika Serikat, Australia, Brasil, Cina, Ekuado, Filipina, dan India (Sutarno dan Setyawan, 2015). Beberapa jenis hutan yang dimiliki Indonesia adalah hutan tropis dan hutan mangrove (Triwibowo et al., 2014). Hutan tropis di Indonesia, Brasil dan Kongo merupakan wilayah dengan keanekaragaman spesies darat tertinggi (Sutarno dan Setyawan, 2015). Peran penting hutan sebagai paru-paru kota bagi kehidupan masyarakat tidak dipungkiri lagi (Simalongo, et al. 2014). Namun, seiring berjalannya waktu, laju pertumbuhan penduduk semakin meningkat sehingga menimbulkan dampak negatif terhadap lingkungan fisik kawasan hijau di wilayah pedesaan maupun perkotaan (Kementrian kehutanan, 2012).

Kepedulian pemerintah terhadap ancaman rusaknya kawasan hijau adalah diupayakan kawasan hijau binaan dalam wujud "hutan kota" sejak tahun 1980an (Kementrian kehutanan, 2012). Salah satunya yaitu kawasan wisata hutan kota, hutan lindung Kota Langsa yang berada di Gampong Paya Pujok Silemak, Langsa, Aceh (Wibowo, et al. 2021). Selain hutan lindung, kota Langsa juga memiliki Hutan Mangrove Kuala Langsa yang terletak di Gampong Kuala Langsa Kecamatan Langsa Barat (Mardina et al., 2020; Safuridar dan Andiny, 2020). Hutan Lindung Kota Langsa memiliki keanekaragaman jenis pohon sekitar 62 jenis pohon dengan jumlah 1273 pohon (Taman Hutan Kota Langsa, 2021) (tabel 1, gambar $1)$.

Tabel 1. Daftar pohon yang terdapat pada Taman Hutan Lindung Kota Langsa

\begin{tabular}{|c|c|c|c|}
\hline No. & $\begin{array}{l}\text { Jenis } \\
\text { Pohon }\end{array}$ & Nama Latin & $\begin{array}{l}\text { Juml } \\
\text { ah }\end{array}$ \\
\hline 1. & Damar & $\begin{array}{l}\text { Agathis } \\
\text { dammara }\end{array}$ & 447 \\
\hline 2 & $\begin{array}{l}\text { Krueng } \\
\text { babi }\end{array}$ & & 45 \\
\hline 3 & $\begin{array}{l}\text { Krueng } \\
\text { air }\end{array}$ & & 5 \\
\hline 4 & $\begin{array}{l}\text { Krueng } \\
\text { minyak }\end{array}$ & $\begin{array}{l}\text { Dipterocarp } \\
\text { us } \\
\text { humeratus }\end{array}$ & 23 \\
\hline 5 & Semaram & Palaquium & 15 \\
\hline 6 & Matare & & 15 \\
\hline 7 & Pinus & $\begin{array}{l}\text { Cupressus } \\
\text { lusitanica }\end{array}$ & 10 \\
\hline 8 & Cemara & $\begin{array}{l}\text { Casuariacea } \\
e\end{array}$ & 47 \\
\hline 9 & Tampui & $\begin{array}{l}\text { Baccaurea } \\
\text { macrocarpa }\end{array}$ & 27 \\
\hline 10 & Meranti & Shorea sp & 35 \\
\hline
\end{tabular}


Jurnal Jeumpa, 8 (1) Januari -Juni 2021

\begin{tabular}{|c|c|c|c|}
\hline 11 & Cenggal & $\begin{array}{l}\text { Neobalanoc } \\
\text { arpus heimii }\end{array}$ & 40 \\
\hline 12 & $\begin{array}{l}\text { Sembara } \\
\text { ng merah }\end{array}$ & & 13 \\
\hline 13 & $\begin{array}{l}\text { Pasak } \\
\text { bumi }\end{array}$ & $\begin{array}{l}\text { Eurycoma } \\
\text { longifolla }\end{array}$ & 23 \\
\hline 14 & $\begin{array}{l}\text { Sembara } \\
\text { ng keras }\end{array}$ & & 325 \\
\hline 15 & Tempiris & $\begin{array}{l}\text { Sloetia } \\
\text { elongate }\end{array}$ & 143 \\
\hline 16 & $\begin{array}{l}\text { Medang } \\
\text { tanduk }\end{array}$ & & \\
\hline 17 & Manggis & $\begin{array}{l}\text { Garcinia } \\
\text { mangostana }\end{array}$ & 3 \\
\hline 18 & Rambe & $\begin{array}{l}\text { Baccurea } \\
\text { motletana }\end{array}$ & 15 \\
\hline 19 & $\begin{array}{l}\text { Sentul } \\
\text { hutan }\end{array}$ & $\begin{array}{l}\text { Sandrocium } \\
\text { koetjape }\end{array}$ & 57 \\
\hline 20 & Merbabu & $\begin{array}{l}\text { Botanis } \\
\text { intsia spp }\end{array}$ & 17 \\
\hline 21 & Sengon & Albisia $s p$ & 58 \\
\hline 22 & Sentang & $\begin{array}{l}\text { Azadirachta } \\
\text { exxelsa }\end{array}$ & 63 \\
\hline 23 & $\begin{array}{l}\text { Rambung } \\
\text { /karet }\end{array}$ & $\begin{array}{l}\text { Havea } \\
\text { braziliensis }\end{array}$ & 10 \\
\hline 24 & Jabon & $\begin{array}{l}\text { Anthocephal } \\
\text { us cadamba }\end{array}$ & 15 \\
\hline 25 & $\begin{array}{l}\text { Trompet } \\
\text { hutan }\end{array}$ & $\begin{array}{l}\text { Brugamansi } \\
\text { a suaveolens }\end{array}$ & 7 \\
\hline 26 & $\begin{array}{l}\text { Kopi } \\
\text { Arabica }\end{array}$ & $\begin{array}{l}\text { Coffea } \\
\text { arabica }\end{array}$ & 10 \\
\hline 27 & $\begin{array}{l}\text { Sentol } \\
\text { manis }\end{array}$ & $\begin{array}{l}\text { Sandrocium } \\
\text { koetjape }\end{array}$ & 6 \\
\hline 28 & $\begin{array}{l}\text { Cembeda } \\
\mathrm{k} \text { hutan }\end{array}$ & $\begin{array}{l}\text { Artocarpus } \\
\text { integer }\end{array}$ & 25 \\
\hline 29 & Bendoe & $\begin{array}{l}\text { Artocarpus } \\
\text { elasticus }\end{array}$ & 33 \\
\hline 30 & Kantil & $\begin{array}{l}\text { Michella } \\
\text { alba }\end{array}$ & 7 \\
\hline
\end{tabular}

\begin{tabular}{|c|c|c|c|}
\hline 31 & Salam & $\begin{array}{l}\text { Syzgium } \\
\text { polyabthum }\end{array}$ & 7 \\
\hline 32 & Serot & $\begin{array}{l}\text { Streblus } \\
\text { asper }\end{array}$ & 13 \\
\hline 33 & Gandri & & 435 \\
\hline 34 & Surien & Toona & 7 \\
\hline 35 & Nibong & $\begin{array}{l}\text { Oncosperma } \\
\text { tigliarium }\end{array}$ & 13 \\
\hline 36 & Durian & $\begin{array}{l}\text { Durio } \\
\text { zibethirus }\end{array}$ & 25 \\
\hline 37 & Alim & $\begin{array}{l}\text { Lempidium } \\
\text { sativum }\end{array}$ & 2 \\
\hline 38 & $\begin{array}{l}\text { Bambu } \\
\text { botol }\end{array}$ & $\begin{array}{l}\text { Schizostachy } \\
\text { um zollingeri }\end{array}$ & 1 \\
\hline 39 & $\begin{array}{l}\text { Bambu } \\
\text { galah }\end{array}$ & & 2 \\
\hline 40 & $\begin{array}{l}\text { Bambu } \\
\text { kuning }\end{array}$ & $\begin{array}{l}\text { Bambusa } \\
\text { vulgaris }\end{array}$ & 5 \\
\hline 41 & Laban & Vivet $\mathrm{sp}$ & 63 \\
\hline 42 & Sentalon & & 1 \\
\hline 43 & Hasan & Pterocarpus & 435 \\
\hline 44 & Ranbutan & $\begin{array}{l}\text { Nephelium } \\
\text { lappaceum }\end{array}$ & 13 \\
\hline 45 & Gelugur & $\begin{array}{l}\text { Garcina } \\
\text { atroviridis }\end{array}$ & 3 \\
\hline 46 & Mangga & $\begin{array}{l}\text { Mangifera } \\
\text { indica }\end{array}$ & 30 \\
\hline 47 & Mahoni & $\begin{array}{l}\text { Switernia } \\
\text { macrophylla }\end{array}$ & 63 \\
\hline 48 & $\begin{array}{l}\text { Jeruk } \\
\text { manis }\end{array}$ & $\begin{array}{l}\text { Citrus } \\
\text { sinensis }\end{array}$ & 2 \\
\hline 49 & Pinang & $\begin{array}{l}\text { Areca } \\
\text { catechu }\end{array}$ & 2 \\
\hline 50 & Duku & $\begin{array}{l}\text { Lansium } \\
\text { domesticum } \\
\text { corr }\end{array}$ & 5 \\
\hline 51 & Kurma & P.dasctyfera & 25 \\
\hline 52 & Paha rusa & & 35 \\
\hline 54 & $\begin{array}{l}\text { Jambu } \\
\text { Hutan }\end{array}$ & $\begin{array}{l}\text { Syzygium } \\
\text { spp }\end{array}$ & 20 \\
\hline
\end{tabular}




\begin{tabular}{|c|c|c|c|}
\hline \multirow[t]{2}{*}{55} & Cengkeh & Eugenia & 33 \\
\hline & Hutan & aromatic & \\
\hline \multirow[t]{2}{*}{56} & Asam & Taramindus & 5 \\
\hline & Jawa & indica & \\
\hline 57 & Kunci & & 1 \\
\hline 58 & Merah & & 2 \\
\hline 59 & Jelutong & $\begin{array}{l}\text { Dyera } \\
\text { costulata }\end{array}$ & 9 \\
\hline 60 & Kemiri & $\begin{array}{l}\text { Aleurites } \\
\text { moluccanus }\end{array}$ & 15 \\
\hline \multirow[t]{3}{*}{61} & Medang & & 1 \\
\hline & Wangi & & \\
\hline & & JUMLAH & 1273 \\
\hline
\end{tabular}

Hutan kota didefinisikan sebagai kawasan vegetasi berkayu di wilayah perkotaan yang memiliki fungsi penting yaitu proteksi (penangkal polusi udara dan suara, kelestarian tanah, ameliorasi, tata air), estetika, dan rekresai (Akbar, 2019). Adapun Peraturan Pemerintah No. 63 (2002), mendefinisikan Hutan Kota sebagai hamparan lahan yang pepohonannya tumbuh kompak/rapat dalam wilayah perkotaan baik pada tanah negara maupun tanah hak, dan ditetapkan sebagai hutan kota oleh pejabat yang berwenang. Pentingnya peranan hutan kota untuk masyarakat dipengaruhi kesehatan hutan. Menurut Yunasfi (2002) kesehatan hutan ditandai dengan kesehatan pohon; pohon dikatakan sehat apabila pohon dapat menjalankan fungsi fisiologisnya dan mempunyai ketahanan ekologi yang baik terhadap gangguan dari serangan hama serta berbagai faktor luar lainnya. Penurunan kesehatan pohon dapat dilihat berdasarkan berbagai bentuk kondisi kerusakan pohon. Kerusakan pohon yang terjadi dapat disebabkan oleh berbagai faktor seperti penyakit dan serangan hama (Pertiwi et al. 2019). Oleh karena itu penelitian merupakan langkah awal untuk pencegahan dan penanggulangan hama dan penyakit tanaman dengan mengetahui/ mengidentifikasi tipe penyakit pohon yang terdapat di Taman Wisata Hutan Lindung Kota Langsa.

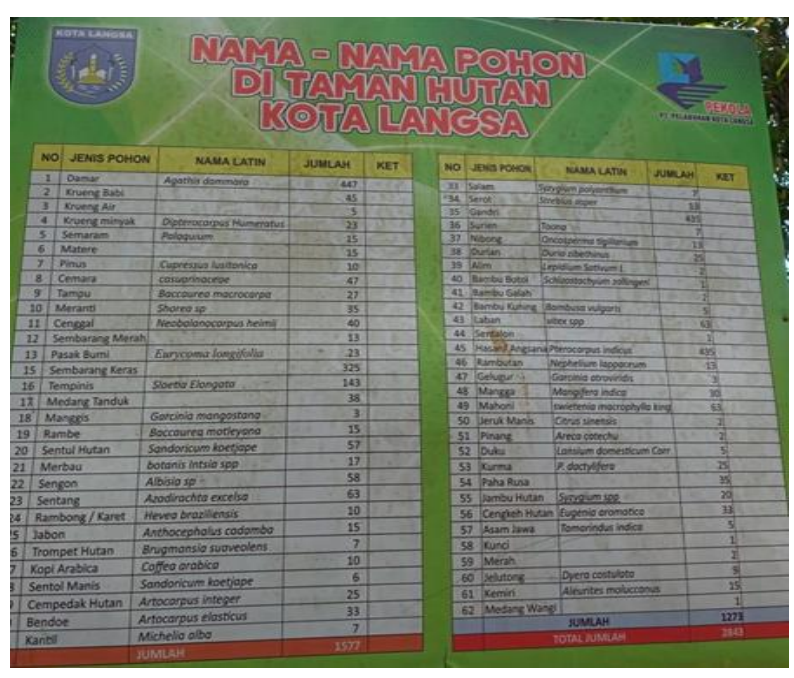


Gambar 1. Nama-nama pohon di Taman Hutan Kota Langsa

\section{Metode Penelitian}

Metode yang digunakan pada penelitian ini adalah metode jelajah (Cruise method) dengan pengamatan langsung terhadap objek yang diteliti (Wibowo, et al. 2021). Lokasi penelitian yaitu di kawasan Hutan Lindung Paya Bujok Seulemak Langsa Baro Kota Langsa dengan luas $\pm 10 \mathrm{Ha}$ (Gambar 2). Penelitian dilakukan pada April - Mei 2021. Alat-alat yang digunakan dalam penelitian ini adalah peta lokasi penelitian, alat tulis dan

\section{Hasil dan Pembahasan}

Hasil observasi dilapangan diperoleh jenis-jenis/ tipe kerusakan yang diakibatkan oleh serangan hama dan penyakit pada beragam jenis pohon yang ada di Taman Wisata Hutan Lindung Kota Langsa disajikan pada tabel 2 dan gambar 3 .

Tabel 2. Jenis pohon yang terserang penyakit di Tamn Hutan Lindung Kota Langsa Aceh

Tipe Kerusakan Pohon

\section{Kanker}

Penyakit kanker pohon ditandai dengan matinya kulit kambium dan diikuti oleh matinya kayu dibawah kulit. Kanker pada kamera. Parameter pengamatan berupa bentuk tipe kerusakan penyakit pada pohon, dan jenis-jenis pohon.

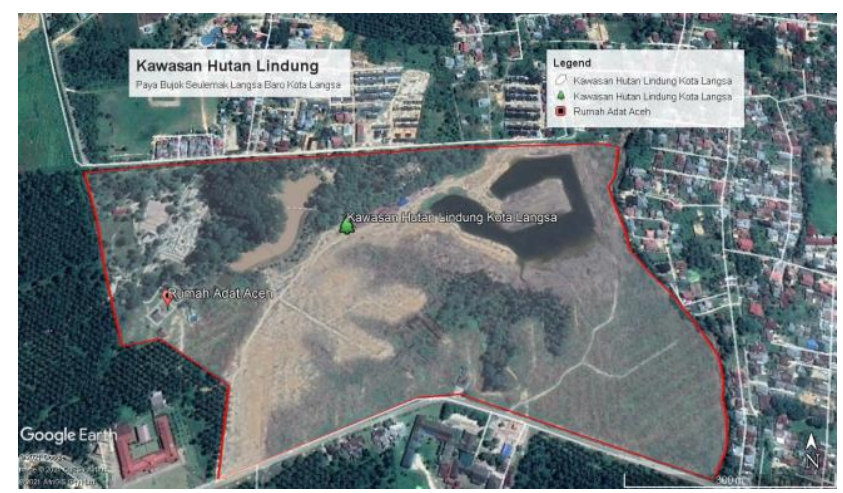

Gambar 2. Peta Lokasi penelitian

Taman Wisata Hutan Lindung Kota Langsa

\begin{tabular}{|c|c|c|c|c|}
\hline No. & $\begin{array}{l}\text { Nama } \\
\text { lokal }\end{array}$ & $\begin{array}{l}\text { Nama } \\
\text { ilmiah }\end{array}$ & Famili & Tipe kerusakan \\
\hline 1. & Kayu alim & $\begin{array}{l}\text { Lepidium } \\
\text { sativum } \mathrm{L} .\end{array}$ & Brassicaceae & Kanker \\
\hline 2. & Tempinis & $\begin{array}{l}\text { Sloetia } \\
\text { elongata }\end{array}$ & Moraceae & Luka terbuka \\
\hline 3. & $\begin{array}{l}\text { Cemara } \\
\text { sumatra }\end{array}$ & $\begin{array}{l}\text { Taxus } \\
\text { baccata } \mathrm{L} .\end{array}$ & Taxaceae & Gerowong \\
\hline 4. & Jati & $\begin{array}{l}\text { Tectona } \\
\text { grandis } \\
\text { L.f. }\end{array}$ & Lamiaceae & Brum \\
\hline 5. & Puring & $\begin{array}{l}\text { Croton } \\
\text { laevigatus } \\
\text { Vahl }\end{array}$ & Euphorbiaceae & $\begin{array}{l}\text { Keropos kayu atau } \\
\text { terdapat rayap }\end{array}$ \\
\hline 6. & $\begin{array}{l}\text { Pasak } \\
\text { bumi }\end{array}$ & $\begin{array}{l}\text { Eurycoma } \\
\text { longifolia }\end{array}$ & Simaroubaceae & $\begin{array}{l}\text { Terserang } \\
\text { cendawan }\end{array}$ \\
\hline
\end{tabular}

pohon banyak dijumpai pada batang pohon. Apabila penyakit kanker pohon tidak langsung dilakukan pencegahan maka akan mengakibatkan kualitas kesehatan pohon menurun atau bahkan lama-kelamaan dapat 
menyebabkan kematian pada pohon terkhususnya pada pohon kayu alim (Lepidium sativum L.) Kayu alim (Lepidium sativum L.) yaitu jenis kayu yang seluruh organ-organ tanamannya dapat dimanfaatkan sebagai bahan campuran dalam pembuatan

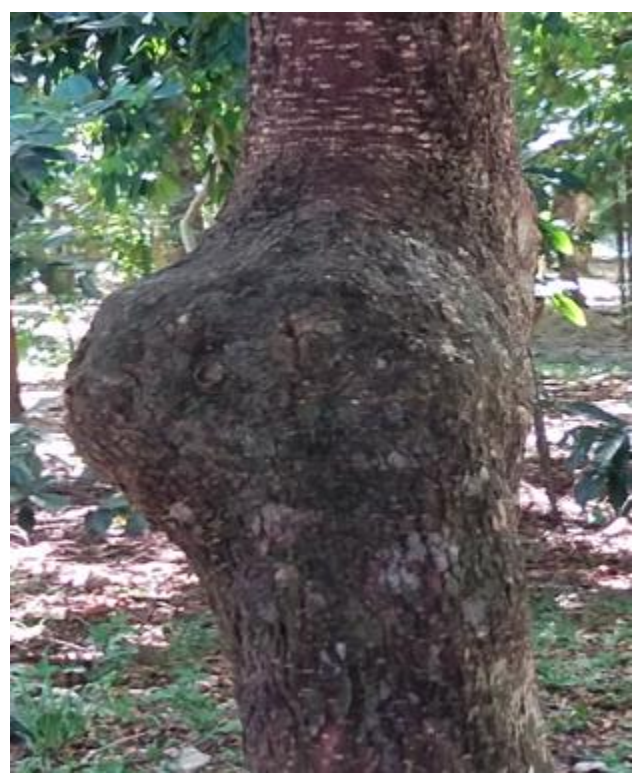

(a) Kanker pada batang pohon kayu alim (Lepidium sativum L.)

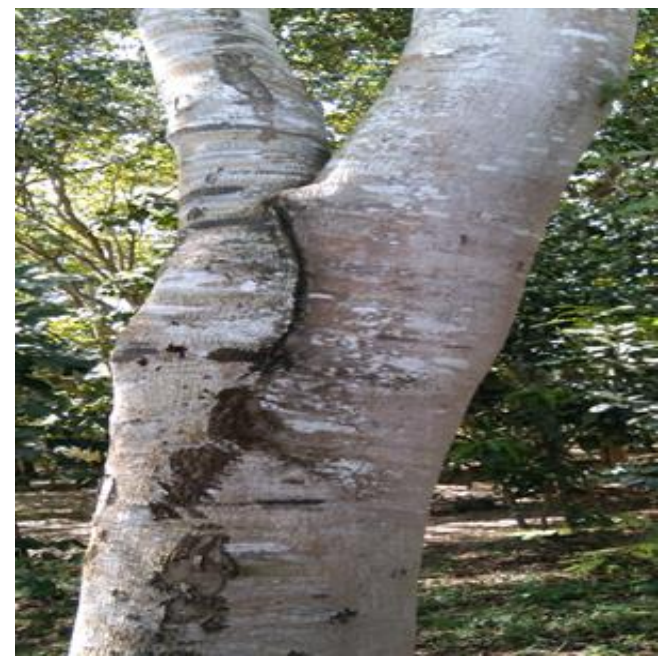

(c) Gerowong pada pohon cemara sumatra (Taxus baccata L.) obat-obatan tradisional. Kayu alim sendiri merupakan jenis kayu yang termasuk kedalam famili Brassicaceae. Gambar 3a menunjukkan bahwa kerusakan yang terjadi pada pohon kayu alim (Lepidium sativum $\mathrm{L}$.) berupa penyakit kanker.

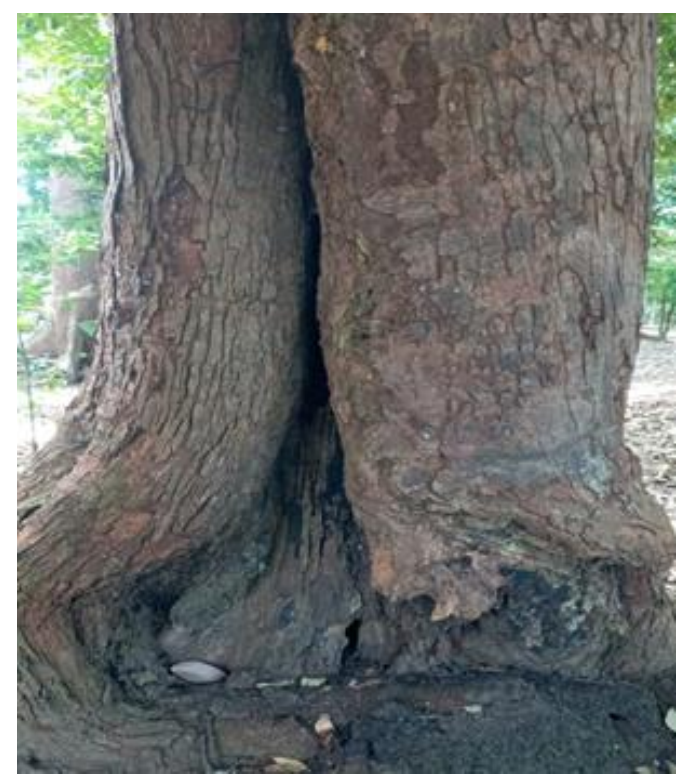

(b) Luka terbuka pada tempinis (Sloetia elongata)

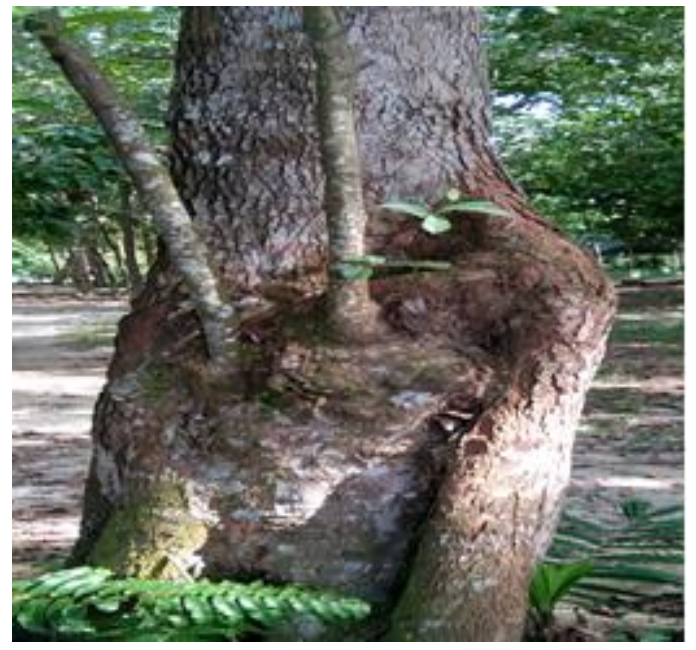

(d) Brum pada pohon jati (Tectona grandis L.f.). 


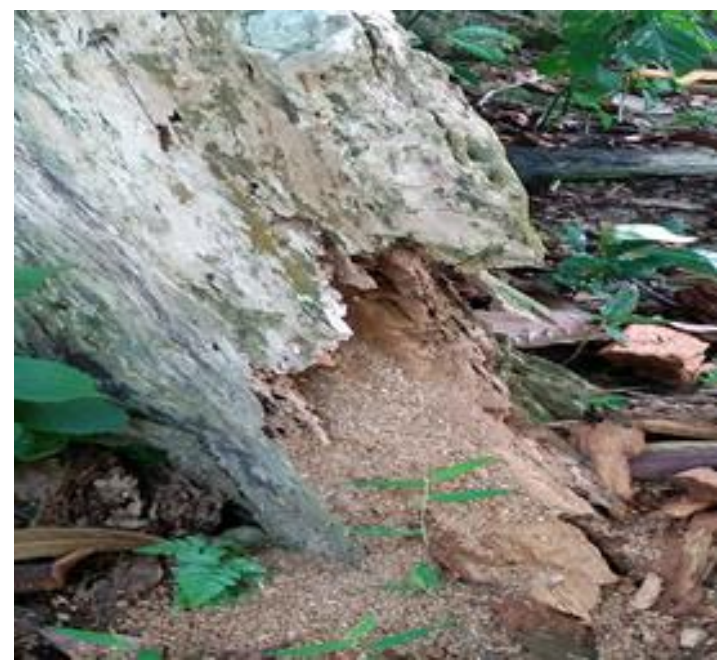

(e) Keropos kayu atau terdapat rayap pada pohon puring (Croton laevigatus Vahl)

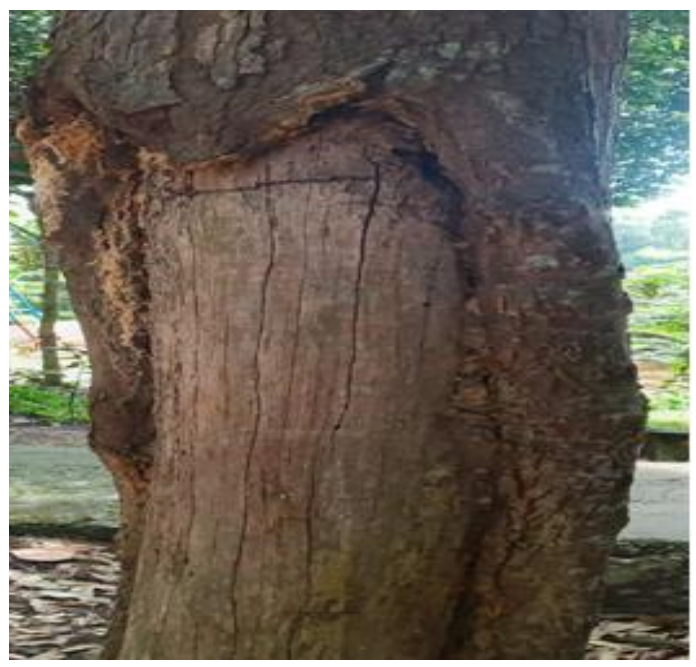

(f) batang terserang cendawan pada pohon pasak bumi (Eurycoma longifolia)

Gambar 3. jenis-jenis kerusakan pohon di Taman Wisata Hutan Lindung Kota Langsa

\section{Luka terbuka}

Menurut (Simajorang dan Rahmat, 2018) luka terbuka yang terdapat mempermudah jalan masuknya mikroorganisme patogen seperti virus, bakteri, jamur, hama pengganggu dan organisme lainnya sehingga dapat menurunkan kondisi kesehatan pohon. Luka terbuka pada penelitian ini ditemui pada pohon tempinis (Sloetia elongata) (gambar 3b). Pohon tempinis adalah jenis pohon yang memiliki kayu yang keras, kuat dan tahan lama. Kayu tempinis termasuk kedalam famili Moraceae. Luka terbuka terlihat dibagian bawah batang. Pohon tempinis yang mengalami tipe kerusakan luka terbuka biasanya diakibatkan oleh perlukaan dengan menggunakan benda tajam seperti tebasan golok atau vandalisme yang dilakukan secara sengaja oleh manusia yang tidak bertanggung jawab.

\section{Gerowong}

Gerowong memiliki ciri-ciri adannya lubang pada batang pohon dengan ukuran lubang yang cukup besar. Kerusakan gerowong pada pohon Cemara Sumatra (gambar 3c) disebabkan karena adanya serangan dari hama perusak pohon, sehingga terbentuk lubang besar pada pohon cemara sumatra (Pertiwi, et al. 2019). Pohon Cemara sumatra merupakan jenis pohon yang termasuk kedalam famili Taxaceae dan sering dijumpai didataran tinggi dengan ketinggian rata-rata mencapai 1500-2500 m dpl (Dibawah permukaan laut) (Frianto dan Novriyanti, 2016). 


\section{Brum}

Pohon jati (Tectona grandis L.f.) merupakan jenis pohon penghasil kayu terbesar diindonesia dengan memiliki ciriciri yaitu batang kayu yang lurus, daun lebar dan menggugurkan daun pada saat musim kemarau tiba. Pada saat musim kemarau daun mengalami perubahan warna diakibatkan karena adanya perubahan musim. Perubahan warna ini merupakan salah satu bentuk dari adaptasi pohon jati terhadap perubahan lingkungan dengan tujuan agar dapat mengurangi penguapan untuk dapat bertahan hidup. Setelah terjadinya perubahan warna pohon jati akan menggugurkan daunnya (Simajorang dan Rahmat, 2018). Pohon jati termasuk kedalam famili Lamiaceae. Tipe kerusakan pada pohon jati yaitu Brum (cabang berlebihan) dengan mempunyai tanda seperti tumbuhnya cabang-cabang yang berlebihan pada batang pohon jati (Tectona grandis L.f. (gambar 3d). Hal ini terjadi karena adanya perlukaan yang dilakukan oleh manusia pada saat dilakukannya pemangkasan pada batang pohon jati dengan menggunakan benda tajam. Sehingga menyebabkan kerusakan baru seperti Brum. Adapun perawatan yang dapat dilakukan pada batang pohon jati (Tectona grandis L.f.) yang mengalami tipe kerusakan brum yaitu dengan melakukan pemangkasan kembali pada batang pohon jati (Tectona grandis L.f.) yang terserang penyakit brum dan melakukan perawatan luka pada batang pohon jati (Tectona grandis L.f.) yang telah dilakukan pemangkasan.

5. Keropos kayu atau terdapat rayap

Gambar 3e menunjukkan bahwa kerusakan yang terjadi pada pohon puring (Croton laevigatus Vahl) berupa keropos kayu atau terdapat rayap. Menurut (Simajorang dan Rahmat, 2018) rayap biasanya memanfaatkan kayu sebagai tempat untuk bersarang dan juga sebagai salah satu bagian dari sumber makanannya sehingga akibat dari serangan rayap yang bertahuntahun pada batang pohon puring, maka dapat mengakibatkan terjadinya keropos pada batang kayu puring.

Pohon puring merupakan jenis pohon cemara atau semak dengan memiliki ketinggian pohon sekitar 15 meter. Pohon puring merupakan salah satu jenis pohon yang endemik di China tepatnya hidup dihutan lebat Provinsi Hainan. Pohon puring termasuk kedalam famili Euphorbiaceae (Liao, et al. 2020).

\section{Batang terserang cendawan}

Gambar 3f menunjukkan bahwa kerusakan yang terjadi pada batang pasak 469 
bumi (Eurycoma longifolia) terserang cendawan. Pasak bumi (Eurycoma longifolia) termasuk kedalam jenis pohon yang masuk kedalam famili Simaroubaceae. Pasak bumi merupakan jenis tumbuhan semak yang mempunyai batang berkayu dengan tekstur batang yang keras dan kuat dengan bentuk batang bulat. Warna batang bulat dengan memiliki daun majemuk menyirip ganjil. Bunga pasak bumi bertipe tandan majemuk yang keluar dari ketiak daun. Pasak bumi bereproduksi dengan alat perkembangbiakan generatif yaitu dengan menggunakan bunga, buah, dan biji (Setyaningrum et al. 2017).

\section{Kesimpulan}

Penelitian menyimpulkan ada enam tipe kerusakan yang ditemui pada pohon yang terdapat di Wisata Hutan Lindung Kota Langsa yaitu kanker, luka terbuka, gerowong, brum, keropos kayu atau terserang rayap dan serangan dari cendawan.

\section{Saran}

Disarankan penelitian lanjutan tentang frekuensi keparahan kerusakan pada pohon yang terdapat di Taman Wisata Hutan Lindung Kota Langsa dalam rangka menjaga kesehatan hutan.

\section{Daftar pustaka}

Akbar, R. 2019. Analisis Kesehatan Pohon Di Taman Hutan Kota Dan Taman Buah Lubuk Pakam Kabupaten Deli Serdang. Skripsi. Universitas Sumatera Utara.

Frianto D, Novriyanti. 2016. Pola penyebaran dan potensi kerapatan Taxus sumatrana di Gunung Tujuh, Kabupaten Kerinci, Provinsi Jambi. Jurnal Masy Biodiv Indon, Vol 2(1): 12-15.

Kementerian Kehutanan BPPK. 2012. Jenis pohon potensial untuk pengembangan hutan kota. Policy bried, Vol 6 (11): $1-8$.

Liao X; Hong-Xin W; Zhi-Xin Z; Hua-Feng W. 2020. Urutan plastom lengkap Croton laevigatus Vahl (Euphorbiaceae): spesies endemik di Hainan, China. Jurnal mitochondrial DNA part B. Vol. 5(1): 457-458.

Mardina V; Amri Y; Harmawan T. 2020. Pelatihan teknik hidroponik untuk mengatasi lahan berkadar lahan tinggi pada masyarakat pesisir Gampong Kuala Langsa, Aceh. Indonesian journal of community engagement. Vol. 6(1): 16-22.

Pertiwi D, Rahmat S, Hari K, Indriyanto. 2019. Identifikasi kondisi kerusakan pohon menggunakan metode forest 
Jurnal Jeumpa, 8 (1) Januari-Juni 2021

health monitoring di Tahura War Provinsi Lampung. Jurnal perennial. Vol. 15(1): 1-7.

Safuridar dan Andiny P. 2020. Dampak pengembangan ekowisata Hutan Mangrove terhadap sosial dan ekonomi masyarakat di Desa Kuala Langsa, Aceh. Jurnal samudra ekonomi dan bisnis. Vol. 11(1): 43-52.

Setyaningrum D; S M Kartikawati; Wahdina. 2017. Morfologi pasak bumi (Eurycoma spp) di Dusun Benuah Kabupaten Kubu Raya Kalimantan Barat. Jurnal hutan lestari. Vol. 5(2): 217-224.

Simajorang L P, Rahmat S. 2018. Penilaian vitalitas pohon jati dengan forest health monitoring di KPH Balapulang. Jurnal Ecogreen. Vol. 4(1): 9-15.

Simalongo AO; Agus P; Siti L. 2019. 2014. Identifikasi jenis pohon di Hutan Pendidikan universitas Sumatera Utara. Jurnal peronema forestry science. Vol. 4(3): 303: 308.

Sutarno dan Setyawan A. 2015. Biodiversitas Indonesia: Penurunan dan upaya pengelolaan untuk menjamin kemandirian bangsa. Pros sem nas masy biodiv Indon, Vol 1 (1): $1-13$.

Triwibowo H, Jumani , Emawati H. 2014. Identifikasi hama dan penyakit shorea leprosula miq di taman nasional kutai resort sangkima kabupaten kutai timur provinsi kalimantan timur. Jurnal AGRIFOR, Vol XIII (2): 175 184.

Tuheteru FD; Mahfudz. 2012. Ekologi, manfaat dan rehabilitasi, hutan pantai Indonesia. Manado: Balai penelitian kehutanan Manado.

Wibowo SG, Vivi M, Fadhliani. 2021. Eksplorasi dan identifikasi jenis jamur tingkat tinggi di kawasan Hutan Lindung Kota Langsa. Jurnal biological samudra. Vol. 3(1): 1-13.

Yunasfi. 2002. Faktor-faktor yang mempengaruhi perkembangan penyakit dan penyakit yang disebabkan oleh jamur. Fakultas pertanian. Universitas sumatera utara. Medan. 